\title{
Ticarcillin Disodium
}

National Cancer Institute

\section{Source}

National Cancer Institute. Ticarcillin Disodium. NCI Thesaurus. Code C65205.

The disodium salt form of ticarcillin, a broad-spectrum, semi-synthetic penicillin antibiotic with bactericidal and beta-lactamase resistant activity. Similar to carbenicillin in action, ticarcillin inactivates the penicillin-sensitive transpeptidase C-terminal domain by opening the lactam ring. This inactivation prevents the cross-linkage of peptidoglycan strands, thereby inhibiting the third and last stage of bacterial cell wall synthesis. This leads to incomplete bacterial cell wall synthesis and eventually causes cell lysis. 